CARADDE: Jurnal Pengabdian Kepada Masyarakat
$\begin{gathered}\text { https://journal.ilininstitute.com/index.php/caradde } \\ \text { Volume 2 | Nomor 2 | Februari | 2020 } \\ \text { e-ISSN: } 2621-7910 \text { dan p-ISSN: 2621-7961 }\end{gathered}$
DOI: https://doi.org/10.31960/caradde.v2i2.337

\title{
Program Kemitraan Universitas untuk Penguatan Kelembagaan dalam Mengelola Administrasi dan Keuangan Secara Syariah
}

\section{R Arri Widyanto ${ }^{1,}$ Andi Triyanto ${ }^{2}$ Tuessi Ari Purnomo ${ }^{3}$}

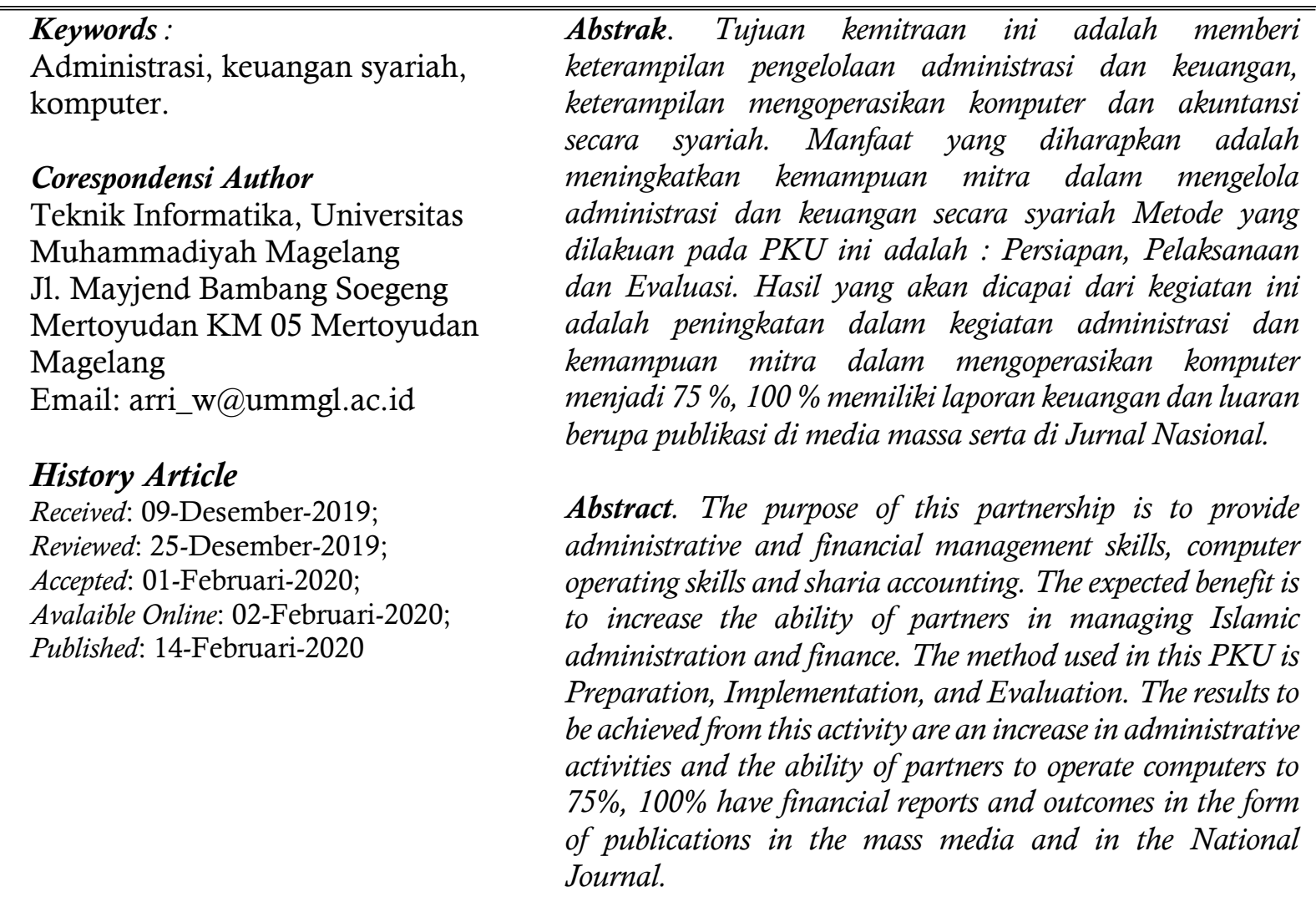

This work is licensed under a Creative Commons Attribution 4.0 International License

\section{PENDAHULUAN}

Dusun Turen merupakan salah satu dusun di Desa Kradenan Kecamatan Srumbung Kabupaten Magelang yang dipimpin oleh seorang Wakil Kepala Dusun. Berdasarkan data monografi penduduk desa Kradenan tahun2018, jumlah penduduk dusun ini terdiri dari 203 Jiwa. Jumlah Kepala keluarga $61 \mathrm{KK}$. Wilayah dusun terdiri dari pemukiman penduduk dan lahan persawahan dan perkebunan. Potensi yang dimiliki adalah : Lahan Pertanian, lahan perkebunan, kolam- kolam ikan, masjid, Taman Pendidikan Al Qur'an (TPQ) serta memiliki kelembagaan seperti PKK, Dasa Wisma RT 01, Dasa Wisma RT 02, Kelompok Tani, Lembaga Keuangan Mikro (LKM) / Koperasi dan Posyandu. (Kradenan, 2018). Lembagalembaga yang akan dijadikan mitra pada kegiatan PKU ini adalah pengurus-pengurus, Kelompok Tani, LKM/Koperasi, PKK dan Dasa Wisma. Semua potensi tersebut belum dikelola dengan baik, terutama berkaitan dengan kegiatan administrasi dan pencatatan keuangannya. 
Semua laporan keuangan seharusnya disajikan secara tertib, jelas dan lengkap sehingga terhindar dari penyimpanganpenyimpangan dan memenuhi prinsip-prinsip akuntansi yang benar. Menurut $(\mathrm{H}$. Malayu S.P. Hasibuan, 2011) menjelaskan bahwa pengelolaan atau manajemen adalah ilmu seni dan seni mengatur proses pemanfaatan sumber daya manusia dan sumber-sumber lainnya secara efektif dan efisien untuk mencapai suatu tujuan tertentu.

Permasalahan yang terjadi pada dusun ini adalah kegiatan administrasi masih dilakukan seadanya menggunakan catatancatatan yang ditulis pada buku tulis atau pada selembar kertas. Masih ada pengurus yang belum biasa mengoperasikan komputer, sehingga untuk membuat dokumen-dokumen harus meminta bantuan orang lain atau menggunakan jasa pengetikan. Undangan disampaikan secara lisan atau menurut kesepakatan misalnya pertemuan setiap malam Ahad di awal bulan, setiap malam Senin Pon dll., sehingga tidak memiliki arsip undangan. Pencatatan keuangan sering tidak sesuai dengan jumlah uang yang ada. Sistem simpan pinjam belum dikelola dengan baik dan belum sesuai dengan prinsip-prisip syariah sehingga masih kental dengan unsur riba.

Solusi dari masalah-masalah tersebut adalah perlu pendampingan pengelolaan administrasi, pelatihan komputer bagi pengurus yang belum bisa mengoperasikan komputer dan memberikan pendampingan bagi pengurus yang sudah bisa mengoperasikan komputer serta diberikan pelatihan akuntansi sederhana, serta memberikan pendampingan system keuangan syariah. Pelatihan adalah suatu proses yang dilakukan untuk mencapai kemampuan tertentu dalam rangka membantu mencapai tujuan organisasi dan diperlukan guna meningkatkan efisiensi, efektivitas, serta produktivitas kerja yang terarah (Lodjo, 2013)

Dari latar belakang tersebut, maka kegiatan kemitraan ini perlu dilaksanakan, terutama untuk mengatasi masalah-masalah yang ditemukan.

Tujuan dari program kemitaan ini adalah Memberi keterampilan pengelolaan administrasi dan keuangan, keterampilan mengoperasikan komputer, terutama program aplikasi perkantoran untuk pengurus kelembagaan dusun dan pendampingannya serta memberikan pelatihan akuntansi secara syariah.

Manfaat yang diharapkan dari kegiatan ini adalah: Potensi yang ditimbulkan dari program kemitraan ini adalah meningkatkan kemampuan mitra dalam mengelola administrasi dan keuangan serta sistem akuntansi syariah. Dari sisi IPTEKS, pengurus kelembagaan bisa memanfaatkan teknologi informasi, terutama teknologi komputer guna menunjang administrasi keuangan yang lebih akuntabel, kredibel dan profesional melalui praktik pembuatan laporan keuangan. Meningkatnya kemampuan kelembagaan untuk meningkatkan kapasitas usahanya untuk mengakses sumber daya modal yang lebih besar. Salah satu faktor pendukungnya adalah kepemilikan dokumen laporan keuangan yang akuntabel, kredibel dan profesional yang menjadi salah satu syarat utama dalam pengajuan pembiayaan di lembaga keuangan. Nilai tambah bagi Universtitas Muhammadiyah Magelang adalah, Kegiatan ini sebagai media mengenalkan institusi kepada masyarakat sasaran.

\section{METODE}

Metode yang dilakukan dalam
kegiatan ini berupa pelatihan dan pendampingan yang terbagi terbagi dalam tiga tahap yaitu : (a) tahap persiapan, (b) tahap pelaksanaan, (c) tahap evaluasi dan (d) penyusunan laporan.

Adapun tahapan kegiatan ini meliputi: Tahap Persiapan. Tahap persiapan dimulai dengan melakukan koordinasi team Pengabdian dengan masyarakat sasaran, yaitu pengurus kelompok tani, membahas rencana kegiatan. Menyiapkan perijinan. Menyusun, menyiapkan materi dan modul pelatihan.

Dilanjutkan Tahap Pelaksanaan. Tahap ini dilaksanakan dalam 4 kegiatan yaitu: (1) Memberi pelatihan dasar-dasar pengoperasian komputer bagi pemula dan pelatihan lanjutan tentang pemanfaatan microsoft office untuk membuat administrasi; (2) Memberi pendampingan penyusunan administrasi organisasi; (3) Memberi pelatihan dasar Excel dan pelatihan lanjutan pengelolaan keuangan organisasi menggunakan aplikasi excel; (4) Memberikan pendampingan pengelolaan keuangan organisasi secara syariah. Tahap 
Evaluasi dilakukan kegiatan: (1) Menguji secara praktik kemampuan menggunakan komputer untuk administrasi dengan materi microsoft word dan microsoft excel, untuk mengetahui peningkatan kemampuan setelah mengikuti pelatihan; (2) Melakukan diskusi bersama pengurus kelembagaan terkait pelaksanaan kegiatan yang sudah dilakukan dan rencana tindak lanjut. Dan diakhir kehiatan melaukan Tahap Penyusunan Laporan: yang dilakukan: (1) Penyusunan Laporan Kemajuan Kegiatan Pengabdian; (2) Penyusunan Laporan Akhir Kegiatan Pengabdian; (3) Penyusunan Draft Jurnal Hasil Pengabdian dan Draft Publikasi

Sasaran program kemitraan ini adalah pengurus Kelembagaan di Dusun Turen, yang terdiri dari pengurus-pengurus Kelompok Tani, Lembaga Keuangan Mikro / Koperasi, PKK dan Dasa Wisma. Lokasi kegiatan berada di Dusun Turen Desa Kradenan Kecamatan Srumbung Kabupaten Magelang Provinsi Jawa Tengah.

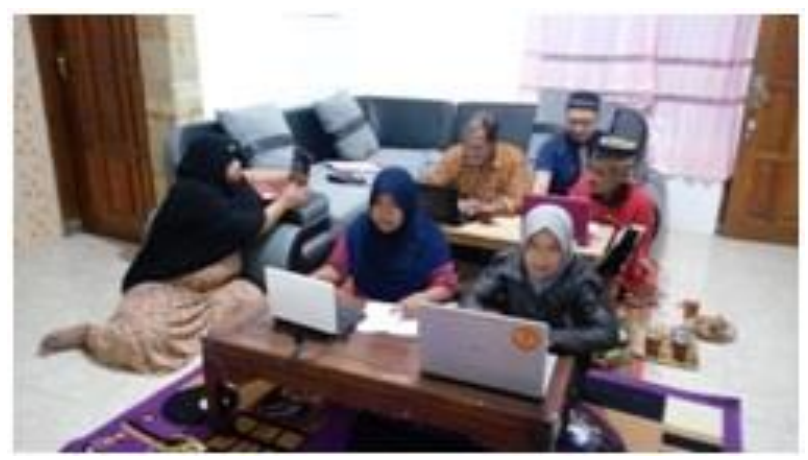

Gambar 1 Pelatihan Pengoperasin Komputer.

Materi pelatihan berupa pendalaman materi menggunakan Microsoft Word dan Microsot Excel. Fungsi utama dari Microsoft Word adalah Sebagai software/program pengolah kata bagi user. Banyak sekali fitur pengolah kata yang mudah difahami dan pelengkap (tool) yang disertakan di dalam Microsoft Word (Ikhwani et al., 2015). Microsoft Excel merupakan perangkat lunak yang mengolah data secara otomatis meliputi perhitungan dasar, penggunaan fungsi-fungsi, pembuatan grafik dan manajemen data (Jarot S., Shenia A., 2012). Secara rinci materi tersebut adalah : Mengatur paragraf, menyisipkan tabel dan gambar.(Kadir, 2005). Selain itu diberikan materi juga fungsi-fungsi logika IF, COUNTIF, VLOOKUP dan Fungsi DATE. Narasumber kegiatan pelatihan
Pengukuran tingkat keberhasilan kegiatan ini dengan menguji secara praktik kemampuan dalam mengoperasikan komputer. Sedangkan pengukuran yang lain, menggunkan kuesioner untuk mendapatkan gambaran tingkat keberhasilan kegiatan ini.

\section{HASIL DAN PEMBAHASAN}

Hasil dari program kemitraan ini berupa kegiatan pendampingan pengelolaan administrasi yang meliputi: (1) Pendampingan pemanfaatan komputer untuk kegiatan administrasi; (2) Pendampingan administrasi dan keuangan syariah. Kegiatan pelatihan komputer dilaksanakan tanggal 18 dan 28 Agustus 2019 dengan materi Microsoft word dan microsoft office. Setiap materi diberikan selama 2 jam yang berupa teori dan praktek. Sesi praktek lebih mengedepankan skill dan kemampuan. (Ikhwani, Budiman, \& Rasyidan, 2015) Foto kegiatan pelatihan komputer terlihat pada gambar 1 berikut :

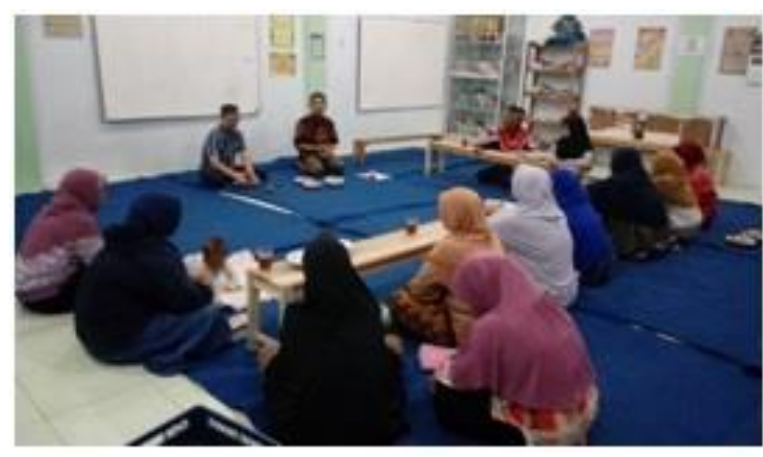

Gambar 2 Pendampingan Tertib administrasi

komputer ini adalah R. Arri Widyanto, S. Kom., MT dari Fakultas Teknik. Target yang akan dicapai kegiatan pelatihan pengoperasian komputer adalah $90 \%$ peserta menguasai pengoperasian komputer, tetapi setelah dilakukan evaluasi ternyata hanya tercapai $82 \%$.

Kegiatan pendampingan administrasi dilaksanakan pada tanggal 4 September 2019 dengan materi : Tertib Administrasi. Materinya berupa tugas dan wewenang pengurus, terutama Ketua, Sekretaris dan Bendahara. Pelaksanaan kegiatan ini bertempat di gedung TPQ Al Muttaqien, dilaksanakan selama 2 Jam. Nara Sumber kegiatan pendampingan ini adalah Andi Triyanto, S. EI., M. SI. Selain itu juga ditekankan pentingnya pencatatan transaksi. 
Caradde: Jurnal Pengabdian Kepada Masyarakat

Vol 2 No 2, Februari 2020

Tanggal 21 dan 27 September dilaksanakan pendampingan pengoperasian komputer dengan materi Microsft Word dan Microsoft Excel.

Kegiatan berikutnya adalah workshop sistem keuangan syariah dengan pemberian materi dan praktek sistem keuangan syariah yang dilaksanakan pada hari Ahad, tanggal 29 September 2019. Kegiatan ini dimulai Jam 09.00 sampai jam 15.00 bertempat di TPQ Al Muttaqien dusun Turen. Kegiatan tersebut terlihat pada Gambar 3. berikut :

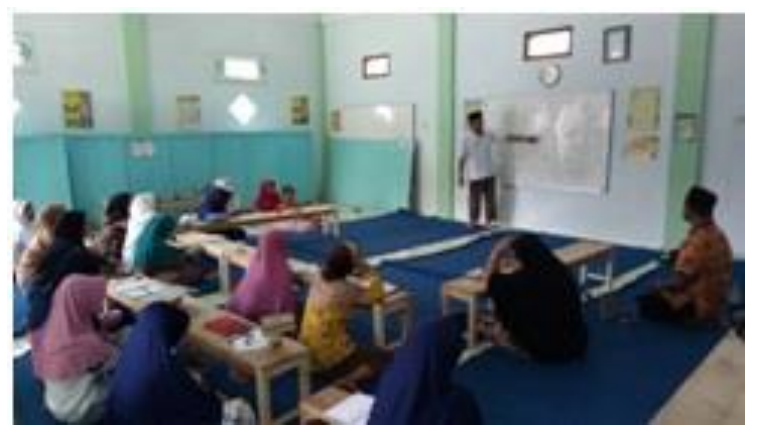

Gambar 3. Workshop Sistem Keuangan Syariah

Akhir kegiatan PKU ini, berupa evaluasi menggunakan quesioner yang dibagikan kepada peserta. Angket atau kuesioner merupakan metode pengumpulan data yang dilakukan dengan cara memberi seperangkat pernyataan atau pertanyaan tertulis kepada responden untuk diberikan respon sesuai dengan permintaan pengguna. (Widoyoko, 2016:33). Setelah semua quesioner diisi oleh peserta, kemudian dilakukan analisis data. Untuk mendapatkan gambaran keberhasilan penyampaian materi pengabdian yang telah dilaksanakan, diadakan post-test dan pengamatan untuk mengetahui peningkatan pengetahuan dan keterampilan peserta tentang pembuatan administrasi dan pengelolaan keuangan kantor dengan menggunakan Program Microsoft Windows dan Microsoft Word dan Microsoft Excel (Arief \& Sukamta, 2018)1. Hasil evaluasi yang dilakukan terlihat pada grafik berikut ini :

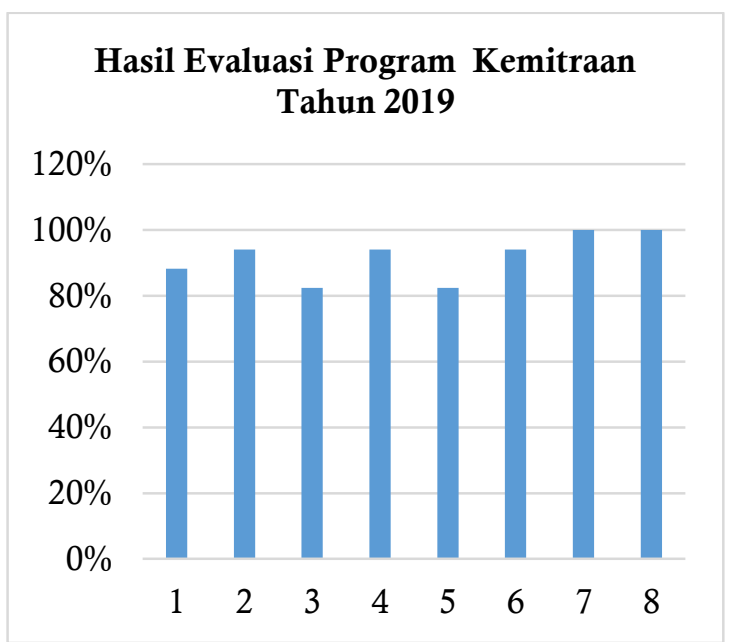

Gambar 4. Hasil Evaluasi Kegiatan

Evaluasi kegiatan oleh peserta diakhir kegiatan menunjukkan bahwa 0,8\% peserta menyatakan materi-materi yang diberikan menunjang kegiatan administrasi yang dikelola. Materi yang diberikan 0,94\% peserta menyatakan runtut dan sistematis. Keterampilan dari peserta $0,82 \%$ sedangkan targetnya adalah $90 \%$. Peningkatan keterampilan peserta ini belum tercapai dari target yang ditetapka. Pemahaman tentang ekonomi syariah $0,94 \%$.

Antusiasme peserta dalam mengikuti kegiatan ini sangat tinggi yaitu $0,94 \%$. Selain itu, peserta juga merasa bahwa kegiatan ini memberikan penyegaran tentang kegiatan administrasi yang telah dilaksanakan, hal ini terlihat $100 \%$ peserta setuju dengan pernyataan ini. Semua peserta menyatakan juga masih memerlukan pelatihan dan pendampingan sejenis dimasa yang akan datang. Hal ini dikuatkan dari hasil evaluasi yang dilakukan oleh Yumniati Agustina, dkk pada pelatihan yang telah dilaksanakan, kemampuan peserta juga meningkat dalam memahami materi pelatihan yang dilakukan (Yumniati Agustina, Sri Setianingsih, 2019)

\section{SIMPULAN DAN SARAN}

Kesimpulan yang dihasilkan dari kegiatan PKU yang sudah dilaksanakan adalah Hasil evaluasi yang dilakukan oleh peserta diakhir kegiatan menunjukkan bahwa $0,8 \%$ peserta menyatakan materi-materi yang diberikan menunjang kegiatan administrasi yang dikelola. Materi yang diberika 0,94 \% 
R Arri Widyanto, Andi Triyanto, Tuessi Ari Purnomo. Program Kemitraan Universitas

peserta menyatakan runtut dan sistematis. Keterampilan dari peserta $0,82 \%$ sedangkan targetnya adalah $90 \%$. Peningkatan keterampilan peserta ini belum tercapai dari target yang ditetapka. Pemahaman tentang ekonomi syariah $0,94 \%$. Antusiasme peserta dalam mengikuti kegiatan ini sanat tinggi yaitu $0,94 \%$. Selain itu, peserta juga merasa bahwa kegiatan ini memberikan penyegaran tentang kegiatan administrasi yang telah dilaksanakan, hal ini terlihat $100 \%$ peserta setuju dengan pernyataan ini. Semua peserta menyatakan juga masih memerlukan pelatihan dan pendampingan sejenis dimasa yang akan datang.

\section{DAFTAR RUJUKAN}

Arief, U., \& Sukamta, S. (2018). Pelatihan Komputer untuk Administrasi Dan Keuangan Pegawai Kelurahan Desa Tegalrejo Kecamatan Tengaran Kabupaten Semarang. Jurnal Abdimas PHB, 1(1), 62-66. Retrieved from http://ejournal.poltektegal.ac.id/index. php/abdimas/article/view/705

H. Malayu S.P. Hasibuan. (2011). Dasar, Pengertian, Dan Masalah. Jakarta: Bumi Aksara.

Ikhwani, Y., Budiman, H., \& Rasyidan, M. (2015). Pelatihan Aplikasi Microsoft Word 2013 Pada SMP H. A. Johansyah. A Banjarmasin. Jurnal Al-Ikhlas, 1(1), 1114.
Jarot S., Shenia A., S. S. (2012). ., Buku Pintar Mocrosoft Office 2007 \& 2010 Word-ExcelPowerPoint. Jakarta: Media Kita.

Kadir, A. (2005). Pengenalan Sistem Informasi. Yogyakarta: Penerbit Andi.

Kradenan, D. (2018). Data Monografi Penduduk Desa Kradenan Kecamatan Srumbung. Magelang.

Lodjo, F. S. (2013). Pengaruh Pelatihan, Pemberdayaan Dan Efikasi Diri Terhadap Kepuasan Kerja. Jurnal Riset Ekonomi, Manajemen, Bisnis Dan Akuntansi, 1(3), 747-755.

Widoyoko, E. P. (2016). Teknik Penyusunan Instrumen Penelitian. Yogyakarta: Pustaka Pelajar.

Yumniati Agustina, Sri Setianingsih, Y. D. S. (2019). Pelatihan Penyusunan Laporan Keuangan Bagi Entitas Mikro, Kecil , dan Menengah Bidang Usaha Dagang pada UMKM Binaan Pusat Inkubasi Bisnis Syariah Majelis Ulama Indonesia. Jurnal Pengabdian Masyarakat: Intervensi Komunitas, 1(1), 1-15. Retrieved from http://ojs.itbad.ac.id/index.php/IK/article/view/24 $2 / 170$ 